\title{
Tourism space versus tourism destination: methodological considerations and empirical testing of their development
}

\author{
LESZEK BUTOWSKI ${ }^{1}$, MARZENA MAKOWSKA-ISKIERKA ${ }^{1}$, WOJCIECH POKOJSKI ${ }^{2}$
}

\begin{abstract}
${ }^{1}$ University of Lodz, Faculty of Geographical Sciences, Institute of Urban Geography and Tourism, Poland; e-mail: leszek.butowski@gmail.com, marzena.makowska@geo.uni.lodz.pl ${ }^{2}$ University of Warsaw, Faculty of Geography and Regional Studies, Poland; e-mail: wpokojski@ uw.edu.pl
\end{abstract}

ABSTRACT The traditional understanding of geographical space as a given place seems to be insufficient nowadays. It should be analyzed in a wider context of social, cultural, economic and environmental aspects and even psychological and emotional factors should be considered. It means that tourism space / destination, which has mostly been treated as a geographical domain, should also be studied as a set of similar factors. In this respect, any tourism space / destination is characterized by complexity and multi-dimensionality, which generate an ontological question concerning its nature. Taking these considerations into account, a research problem related to the essence of tourism space/destination as well as the possibility of its development has been formulated. The problem is followed by the hypothesis that the development of tourism space/destination is measured by the achievement of the state of tourism sustainability. In the empirical part, a method to assess the development of tourism space/destination has been proposed.

KEY WORDS tourism space/destination - sustainability - development - measure - empirical testing - six Polish tourist towns

BUTOWSKI, L., MAKOWSKA-ISKIERKA, M., POKOJSKI, W. (2018): Tourism space versus tourism destination: methodological considerations and empirical testing of their development. Geografie, 123, 1, 85-106.

Received March 2017, accepted October 2017.

CC Česká geografická společnost, z. s., 2018 


\section{Introduction}

For at least several decades, touristic space has been of interest to geographers of tourism and scholars with other academic backgrounds concerned with spatial aspects of tourism (regional economists, country planners and developers, to name only a few). Specifically, Polish and French (francophone) academicians have made attempts at elaborating theoretical foundations of touristic space (the term was used with the Polish adjective turystyczny and French touristique) - mostly from a perspective related to geography (inter alia Butowski 2012, 2014a; Cazelais, Naderu, Beaudet 2000; Drzewiecki 1992; Gołembski 2002; Husbands 1983; Kowalczyk 2014; Liszewski 1995; Meyer 2004; Miossec 1976, 1977; Oppermann 1993; Warszyńska 1986; Warszyńska, Jackowski 1978; Więckowski 2014; Włodarczyk 2009, 2011, 2014).

This scholarly activity started with what appeared to be a huge success in respect of description and measurement of some of the elements of touristic space. Unfortunately, it was followed by a period of stagnation, which has persisted until the present time. To some extent, this stagnation may stem from methodological issues, or, in even broader terms, from a lack of understanding of how research of touristic space is based in ontology and methodology of geographical research of space.

One major problem concerns the definition of space which has been the 'default' one in geography and which sees the term 'space' as relating to specific place, location, terrain, area, territory, region, country, landscape or environment characterized by material and functional parameters; in short, it appears that it is no longer capable to convincingly account for phenomena of the modern world, including tourism-related issues. In order to for research in geography to advance, the aforementioned notions should be analyzed in a broader context, in such a way that they cover also environmental, social, cultural and economic aspects. Furthermore, it has been suggested that an individual's perspective (psychological and emotional factors) be included (Tuan 1987, Jałowiecki 2010). Such an approach seems more appropriate as far as tourism space, which is constantly subject to socio-cultural and economic processes, is concerned (for a definition of the term see Section 2). Needless to say, tourism space seen in this way is characterized by extreme complexity and multi-dimensionality. When one considers the context, it is common sense that tourism space is not only a collection of visited (in the geographical sense) places; it is also distinguished by specific environmental, social, cultural and economic attributes. In addition, it represents certain symbolic and emotional values. It is thanks to these factors that tourism (in general) develops in the given area, which justifies seeing it as tourism space.

Consequently, an increasing number of researchers point to the need to treat tourism space as one in which physical, environmental, socio-cultural, economic 
as well as psychological, emotional and spiritual aspects associated with given destinations are combined (Durydiwka, Duda-Gromada 2015). Thus, the term 'tourism space' covers areas located far beyond geographers' traditional objects of study. Given the 'rediscovered' complexity of the problem, it seems justified to investigate the nature of tourism space one again. Obviously, once the complexity of the issue is correctly diagnosed, it poses another grave question - that of epistemological ability to know and describe such an object of study.

The considerations briefly outlined above call for a research problem related to the nature of contemporary tourism space and the possibility of its development and assessment. The main hypothesis proposes that the measure of development of tourism space is its achievement of the state of tourist sustainability ${ }^{1}$, where sustainability is used to mean an advantage of benefits gained from tourism over costs related to tourism development in a given location. Adoption of such a perspective can contribute to the expansion and enhancement of methodological and theoretical bases of research on tourism space, including ontological and epistemological perspectives. The first part of this paper is concerned primarily with these issues and, thus, it is predominantly theoretical.

The second part of the article includes a new assessment method for determining the level of development of tourism space. It is based on the author's model of sustainable tourism, whose assumptions have provided theoretical foundations. The method is synthetic, which means that various aspects of tourism space in the context of its sustainability or unsustainability can be taken into account. Thus, the method can also serve as a tool for empirical verification of the aforementioned model of sustainability of tourism space. The method was used to conduct a series of studies in the actual environment of six Polish tourist towns (the results of the preliminary and partially research were presented in Butowski 2017). The obtained results (which are also presented in the paper) seem to be interesting enough for further testing and development, especially in the long run. It also appears that the method, thanks to its universal character, can be applied to other destinations and not only for academic but also practical purposes.

\section{Tourism space versus tourism destination: a terminological discussion}

The concepts of 'tourism space' (also 'touristic space') as well as 'tourism destination' have been the notions defined in the literature in question for many years or even decades. Wherein one should notice that in Polish literature the term

1 Such a proposition is in line with the views of $\mathrm{H}$. Spencer, who appreciated that development is connected on the one hand with the increasing differentiation of phenomena but on the other hand with the growth of their integration, ordering and sustainability. 
'touristic space' has more often constituted the object of interest than 'tourism destination'. Contrary to the Anglo-Saxon publications where the notion 'touristic space' has been met relatively rarely while 'tourism destination' (or simply destination) has been commonly used. Taking into account this ambiguous situation in terminology applied in various sources and academic traditions, the question on similarities and differences between those two notions appears. To make the analysis easier and solve the puzzle, the review of chosen definitions of both notions has been made (Table 1).

Table 1 - The chosen definitions of the concepts: 'touristic space' and 'tourism destination'

\begin{tabular}{|c|c|c|c|}
\hline \multicolumn{2}{|l|}{ Touristic space } & \multicolumn{2}{|l|}{ Tourism destination } \\
\hline Author of definition & Definition & Author of definition & Definition \\
\hline $\begin{array}{l}\text { J.M. Miossec } \\
(1976,1977)\end{array}$ & $\begin{array}{l}\text { Touristic space (fr. Espace } \\
\text { touristique) is found at the } \\
\text { borders of work and power } \\
\text { centers. Where tourists go } \\
\text { is a function of the cost and } \\
\text { duration of their journey and } \\
\text { their stay }\end{array}$ & $\begin{array}{l}\text { World Tourism } \\
\text { Organization (http:// } \\
\text { destination.unwto.org/ } \\
\text { content/conceptual- } \\
\text { framework-0, } \\
\text { 24.7.2017) }\end{array}$ & $\begin{array}{l}\text { Tourism destination is a } \\
\text { physical space with or without } \\
\text { administrative and/or analytical } \\
\text { boundaries in which a visitor } \\
\text { can spend an overnight. It } \\
\text { is a cluster (co-location) of } \\
\text { products and services, and of } \\
\text { activities and experiences along } \\
\text { the tourism value chain and a } \\
\text { basic unit of analysis of tourism }\end{array}$ \\
\hline $\begin{array}{l}\text { J. Warszyńska } \\
\text { (1986), Włodarczyk } \\
(2009)\end{array}$ & $\begin{array}{l}\text { Touristic space (pol. } \\
\text { przestrzeń turystyki) is } \\
\text { a part of geographical } \\
\text { space (physical and socio- } \\
\text { economic) in which tourist } \\
\text { phenomena appear }\end{array}$ & $\begin{array}{l}\text { A. Pawlikowska- } \\
\text { Piechotka, N. Łukasik, } \\
\text { A. Ostrowska-Tryzno, M. } \\
\text { Piechotka, K. Sawicka } \\
\text { (2017) }\end{array}$ & $\begin{array}{l}\text { Tourism destination is a place } \\
\text { for tourists to visit and stay, } \\
\text { could be a country, state, } \\
\text { region or city - usually due to } \\
\text { its cultural or natural values }\end{array}$ \\
\hline $\begin{array}{l}\text { S. Liszewski (1995), } \\
\text { Meyer (2004) }\end{array}$ & $\begin{array}{l}\text { Touristic space (pol. } \\
\text { przestrzeń turystyki) is a } \\
\text { functionally distinguished } \\
\text { part of geographical space }\end{array}$ & M. Korstanje (2017) & $\begin{array}{l}\text { Tourism destination is } \\
\text { a geographical place } \\
\text { conditioned to receive tourists } \\
\text { and visitors who are interested } \\
\text { in gazing certain attractions }\end{array}$ \\
\hline $\begin{array}{l}\text { A. Kowalczyk } \\
(2014)\end{array}$ & $\begin{array}{l}\text { Touristic space - sensu largo } \\
\text { (pol. przestrzeń turystyki) is } \\
\text { an objectively existing part } \\
\text { of geographical space and } \\
\text { at the same time of social } \\
\text { (cultural, economic, political) } \\
\text { space }\end{array}$ & M.A. Ferri (2014) & $\begin{array}{l}\text { Tourism destination is one } \\
\text { that is able to differentiate } \\
\text { between the different types } \\
\text { of customers on the basis of } \\
\text { the attractiveness of both its } \\
\text { territorial and instrumental } \\
\text { components }\end{array}$ \\
\hline $\begin{array}{l}\text { M. Więckowski } \\
(2014)\end{array}$ & $\begin{array}{l}\text { Touristic space (pol. } \\
\text { przestrzeń turystyki) is } \\
\text { an area, which is located } \\
\text { outside the everyday lives } \\
\text { of tourists. It should be } \\
\text { adopted for their needs. }\end{array}$ & $\begin{array}{l}\text { The Tourism Society } \\
\text { (http://www. } \\
\text { tourismsociety.org/ } \\
\text { page/88/tourism- } \\
\text { definitions.htm, } \\
\text { 24.7. 2017). }\end{array}$ & $\begin{array}{l}\text { Visitor destinations (the } \\
\text { term preferred to 'tourism } \\
\text { destination' because it includes } \\
\text { all categories of visitor) are the } \\
\text { places for which it is possible } \\
\text { to measure aspects of the } \\
\text { demand for and supply of } \\
\text { tourism services within defined } \\
\text { boundaries }\end{array}$ \\
\hline
\end{tabular}


The primary results of the analysis of meaning of the notions 'touristic space' and 'tourism destination' (and some other e.g. 'tourism area' or 'tourism region') show that there are not more important differences between them. The majority of authors point to the spatial and functional components of both concepts. The latter are usually of geographical character, a place, a town, a region, a country, where certain additional elements, mostly tourist attractions and facilities are located. In turn, the functional side of touristic space/destination is manifested in the presence of tourists (visitors) and services in those areas. All the aforementioned components constitute the attributes of a given touristic space/destination, which enable us to distinguish it from the surrounding higher geographical, social or economic systems. To sum up this initial analysis one may even put a thesis that for more general purposes both concepts can be almost treated as synonyms.

Only a deeper analysis reveals certain features which characterize and differentiate both notions in a more exact way (although it seems that they are of secondary importance - at least from geographical perspective). Firstly the concept 'touristic space' is of spatial character and mostly constitutes the output of geographical sciences. It has also been used rather in an academic environment than in ordinary or professional (business) language. At the same time the term 'tourism destinations' is rather of operational character and has also been used by professionals or academicians mostly connected with tourism economics and management.

Additionally, a deeper analysis of the concept of 'touristic space' made by Kowalczyk (2014) shows that to describe certain phenomena which occur in a given area other related notions were introduced and have been used. The author, studying touristic space from a geographical perspective, but applying a phenomenological approach, lists and defines such notions like: an individual tourist's space (as space perceived subjectively by a tourist), tourists' space (as corporate space perceived by the collectivity of tourists), touristic space - sensu stricte (as space which can be distinguished by the presence of tourists and tourist facilities in a given area), touristic space - sensu largo (as space where occur all tourist phenomena and other phenomena which are the consequences of tourism in a given area). Although the author does not quite agree with this typology, but acknowledges that it is worth mentioning as a theoretical contribution to the discussion of the essence of touristic space.

The concepts of tourism space and tourism destinations have also been applied in other disciplines like tourism sociology and anthropology i.a. in semiotic studies on tourism (e.g. Jokinen, McKie 1997; Urry 2001, 2007; Jenkins 2003, Wieczorkiewicz 2012). In these cases tourism space/destination have not been treated as a given geographical area but rather as a more dematerialized time and space construct, where various signs, symbols, values and experiences play main role.

And finally, in the discussion above, certain linguistic issues should also be considered. As it was earlier mentioned, in the Anglo-Saxon environment the term 
'tourist destination' (or simply 'destination') is commonly used in ordinary, professional and academic language - mostly in economics and management but also in geographical publications. In turn, in the Polish and probably French, Czech, Slovak and Russian academic literature in question, the notion 'touristic space' in various contexts remains dominant. However, to be certain of such a conclusion, it would require further and deeper analysis.

Taking into account the aforementioned considerations, it has been assumed that the concept of 'tourism space' would be understood as a certain geographical space (area) equipped with tourist attractions and facilities, where all tourist and (directly connected with them) other phenomena occur. They can be of spatial, social, economic, cultural, environmental and other characters (the definition corresponds with Kowalczyk's understanding of touristic space sensu largo). In this context tourism space includes elements of materialized physical space but also dematerialized social, cultural, economic, symbolic or even spiritual spaces, which are tied to a given area. Such an understanding of the concept of tourism space has been applied in the paper and treated as synonymous with the term 'tourism destination'. It has also been very useful in the empirical research conducted among people who were not specialists on tourism (it would be impossible for them to distinguish all nuances which differentiate particular types of space where tourism phenomena occur).

\section{Ontology and epistemology of tourism space}

At the beginning of a research project aimed to explore tourism space, the physical subject of study should be determined; specifically, the substantial, spatial and potentially also temporal scope should be defined. Moreover, it is also necessary to determine the aspect(s) in which the study will be carried out (i.e. the formal subject of research, Chojnicki 2005). Subsequently, ontological assumptions are made, stating whether the tourism space to be studied will be considered standalone, real entity or, conversely, a part of a bigger space or system (e.g. geographical, social, economic, cultural). The next step consists in verifying the selected features of a given space in respect of their ability to be used for measurement or characterization of the space; this should be performed considering the selected methodological approach (quantitative vs qualitative $v s$ mixed). At this stage, another important distinction connected with the perception of tourism space should be made: namely, that between the objectivist (neo-positivist) approach and the social constructionism approach. In the former, tourism space is seen as an entity, object or system which remains independent of the researcher. The latter, on the other hand, assumes existence of interrelated feedbacks, which occur between researchers and the subjects of their research. Depending on which of 
the two approaches is adopted, the results may be interpreted very differently, therefore this decision should be well thought out.

The considerations outlined above will obviously impact aspects related to the procedures used for investigation of tourism space. It is also evident that the cognitive perspective requires application of certain basic assumptions: whether tourism space is to be seen as a subject characterized by strong and durable features which allow its distinction from the higher level systems or whether a study of tourism space indicating its specificity and complexity, but at the same time strong interconnections with the external environment, is to be undertaken. One should not exclude the possibility, however, that both approaches are justifiable. On the epistemological level, this calls for a question concerning the type of truth about tourism space which can be discovered: is there an objective truth, as postulated by neo-positivists, or should we expect to find many 'truths' about a given tourism space, as social constructionists would argue (Tribe 2006).

It is very likely that these aspects have not been properly considered in the previous studies of tourism space, ultimately leading to a regress, especially in respect of the development of theoretical and methodological foundations of the research.

All things considered, for the purpose of this paper, the social constructionist methodology is applied with respect to both ontological and epistemological perspective. Such a decision is motivated, among others, by the suitability of this approach to the research method which relies on subjective opinions of different groups of tourism stakeholders.

\section{Problem with the definition of the notion of 'development'}

The discussion of the development of tourism space (or tourism destination) is not possible without an agreed definition of the term 'development'. The problem is that in the literature it is used in an inconsistent manner. The term can probably be traced back to Aristotle, who used it in a teleological (i.e. progressive) sense. In this context, it denoted purposeful change which consisted of passing from lower (less absolute) to higher (more absolute) forms. Herbert Spencer, a philosopher considered with issues of evolution, arrived at similar conclusions. Development understood to mean progress was probably the dominant view throughout the $20^{\text {th }}$ century. Also presently it appears that the term is often used in common language in this meaning.

There is, however, another concept behind this term. It does not refer to the aforementioned teleological reading, as it does not refer to progress; hence, it is called 'neutral'. Instead, it takes 'development' to mean any long-term process of directional changes, in which specific stages (development phases) of a given 
object (system) can be seen to appear one after another. They show the differentiation of the object (system) under the specified terms.

Both the approaches (progressive and neutral) can be found in the majority of current encyclopedic and lexicon publications. ${ }^{2}$

In the geography of tourism and research on tourism space, however, the neutral approach is used more often. Such a stance was taken, among others, by the Polish geographer S. Liszewski (1995) and his followers (Włodarczyk 2009). This author distinguished five types of touristic space (such a name is used by the author) - stages which follow one another but did not assign them the attribute of progress. His focus were the changes of specific parameters (e.g. number of tourists in a given area or the intensity of adaptation thereof for tourist purposes) in given periods of time. In addition, the neutral approach was applied by $\mathrm{Bu}-$ towski (2014a, 2015), who argued the opposite (in relation to Liszewski's typology), namely a temporal sequence of changes occurring in tourist marine and coastal areas without assigning them any attributes of values.

Wrapping this short discussion on the meaning of development up, it can be noted that in any case (meaning it is recognized by all authors) it is a process whose main feature is change. It entails creation of a new (in relation to the previous stage) entity (object, system). The lack of agreement concerns the question about the extent to these changes are purposeful (i.e. progressive) and from which perspective this progression should be assessed. In other words, the doubts revolve around the problem seeing the new objects (created as a result of development changes) as either necessarily 'better' or just 'different' in relation to the preceding stages.

One possible solution to the dilemma outlined above may be to adopt an axiological approach, i.e. to introduce ideas of value. Specifically, it entails evaluation of the object of interest as per the rule: better = more valuable; worse = less valuable. To enable such an approach to the evaluation of tourism space development, the progressive understanding of the term should be applied.

This follows from the fact that any assessment ranks objects on an adopted scale - from worse (or less developed) to better (or more developed). In the context of this paper, this can be interpreted as the given tourism space being less or more developed than others - with the assumed element of valuation.

It is evident that in evaluation the problem of perspective from which it is conducted will certainly occur. The issue is particularly important in the case

2 For example: http://www.businessdictionary.com/definition/development.html (6.1. 2017), https://www.merriam-webster.com/dictionary/development (6.1.2017), http://sjp.pwn.pl/ szukaj/rozw\%C3\%B3j.html (6.1.2017), although in the French editions (in particular those connected with social sciences and humanities) the progressive understanding of the notion still seems to prevail - e.g. http://www.hypergeo.eu/spip.php?article511 (6.1.2017), http:// www.toupie.org/Dictionnaire/Developpement.htm (6.1.2017). 
of evaluating tourism space, because such an evaluation can be performed from the perspective of various social groups with their obviously differing needs and expectations (different entities which benefit from tourism in a given area, e.g. tourists $v s$ local communities including entrepreneurs, employees, local authorities and others).

The author of this paper faced all the aforementioned problems and doubts and, having considered pros and cons the neutral and progressive interpretations of the term 'development', decided to adopt in the paper the progressive interpretation. The rationale for this decision is the need to investigate the relationship between development and evaluation thereof (from the axiological perspective) taking into account different perspectives of the stakeholders of tourism in a given area (destination).

\section{Sustainability of Tourism Space}

The concept of sustainability of tourism space is related to a wider idea of sustainable tourism. Unfortunately, despite the fact that numerous scholars have devoted their attention to this issue, approaching it from the perspectives of various disciplines, there still is no single definition of sustainable tourism that would be commonly recognized. Approaches applied so far to present the main ideas and features of sustainable tourism ${ }^{3}$ differed significantly, also with respect to the initial assumptions (see, e.g., Butler 1999; Butowski 2014b; Kowalczyk 2010; Niezgoda 2006). Still, a majority of the propositions considered sustainable development a generic notion (Coccossis, Parpairis, Nijkamp 1995; Forsyth 1997; Harris, Leiper 1995; Hunter 1997; Lanfant, Graburn 1992; Liu 2003, and many others). As a result of this troublesome situation, for the purpose of this paper the following assumption has been made: sustainability of tourism space occurs when the benefits of tourism development (in a given area) achieve at least a minimal satisfactory level and at the same time widely understood costs do not exceed the level which is considered acceptable. This assumption is expressed in Figure $1^{4}$. Where:

- Bstmin (minimum acceptable benefits): denotes the minimum acceptable level of satisfying the needs of all groups of stakeholders, beneath which the reaped

3 Other names for the phenomenon have also been proposed, e.g. W. Hetzer introduced as early as in 1965 the term of responsible tourism (as cited in Blamey 2001; Kowalczyk 2010; Leslie 2012). J. Krippendorf (1986) suggested alternative tourism by way of opposition to mass tourism. H. Ceballos-Lescuráin was probably the first to use the term ecotourism in 1987 (Kowalczyk 2010).

4 A detailed presentation of the model of sustainable tourism can be found in Butowski (2014b). 


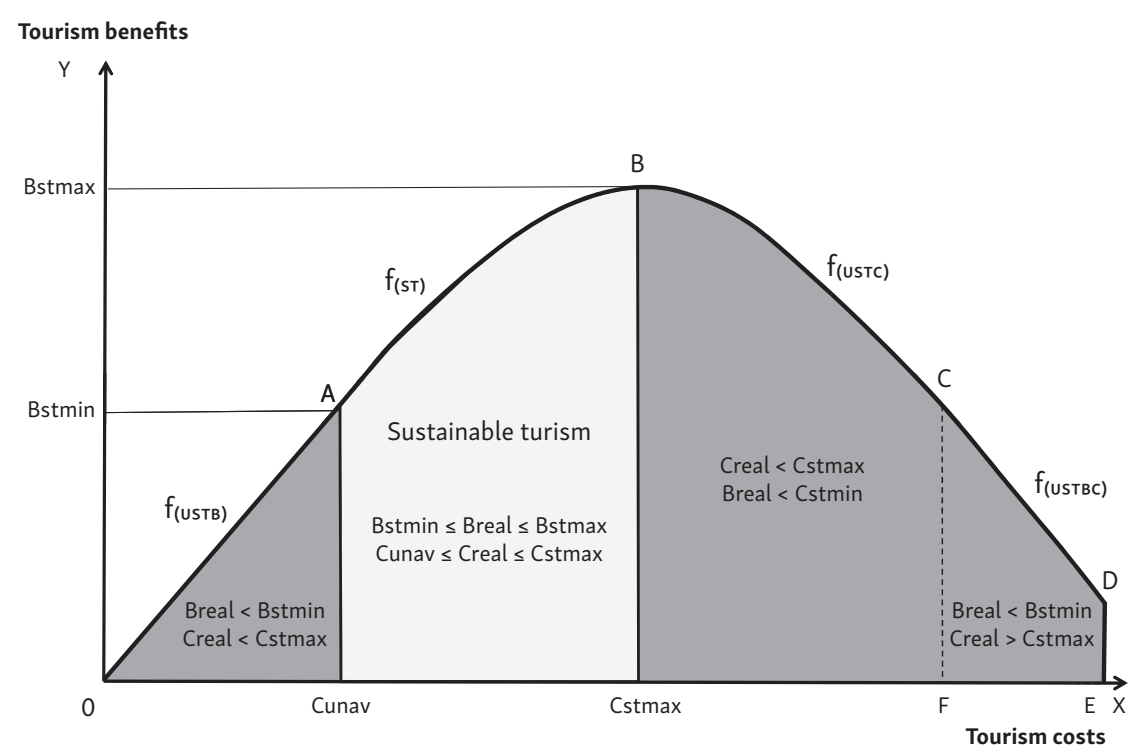

Fig. 1 - Model of sustainable tourism (tourism space). Source: Butowski, 2014b (changed).

benefits will be evaluated as insufficient; it is expressed by a value of the Bstmin point on the Oy axis of the model graph;

- Bstmax (maximum sustainable benefits): denotes the maximum desirable level of satisfying the needs of all groups of stakeholders; it is expressed by a value of the Bstmax point on the Oy axis of the model graph;

- Breal (real benefits): the real level of benefits reaped by tourism stakeholders in a given area (tourism space/destination).

- Cstmax (maximum acceptable costs): denotes the maximum (in sustainable tourism conditions) level of all costs resulting from the development of tourism, which the stakeholders of tourism in a given area (tourism space/ destination) are ready to bear; it is expressed by a value of the Cstmax point on the $\mathrm{Ox}$ axis of the model graph;

- Cunav (unavoidable costs): denotes the level of unavoidable costs resulting from the development of tourism; it is expressed by a value of the Cunav point on the Ox axis of the model graph;

- Creal (real costs): the real level of costs incurred by all stakeholders as a result of the development of tourism in a given area (tourism space/destination);

- $f_{\text {(USTB) }}$ - the function of the lack of sustainability of tourism (tourism space or destination) in the segment of benefits;

- $f_{(\mathrm{ST})}$ - the function of sustainability of tourism (tourism space or destination);

- $f_{\text {(USTC) }}$ - the function of the lack of sustainability of tourism (tourism space or destination) in the segment of costs; 
- $f_{\text {(USTCB) }}$ the function of the lack of sustainability of tourism (tourism space or destination) in both segments i.e. benefits and costs.

The model presented above is static; if the factor of time is taken into consideration, the following three basic variants of long-term changes in the system can be distinguished (Fig. 2-4).

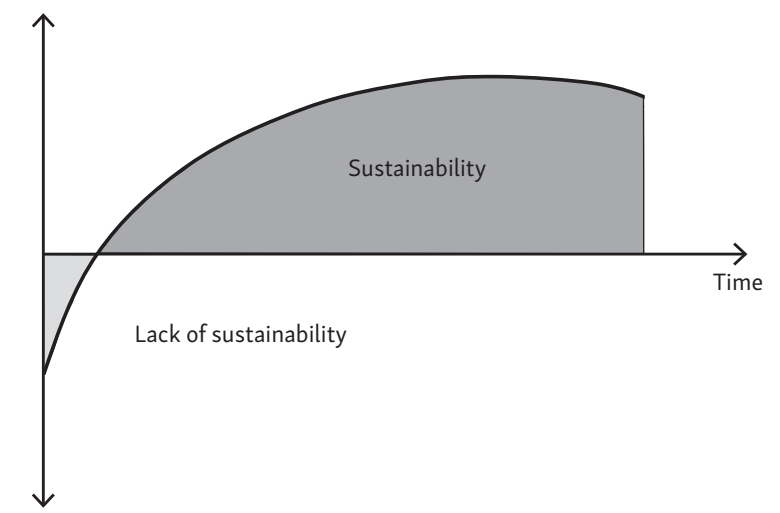

Fig. 2 - Long-term state of sustainability of tourism space / destination. Source: Butowski, 2017 (changed).

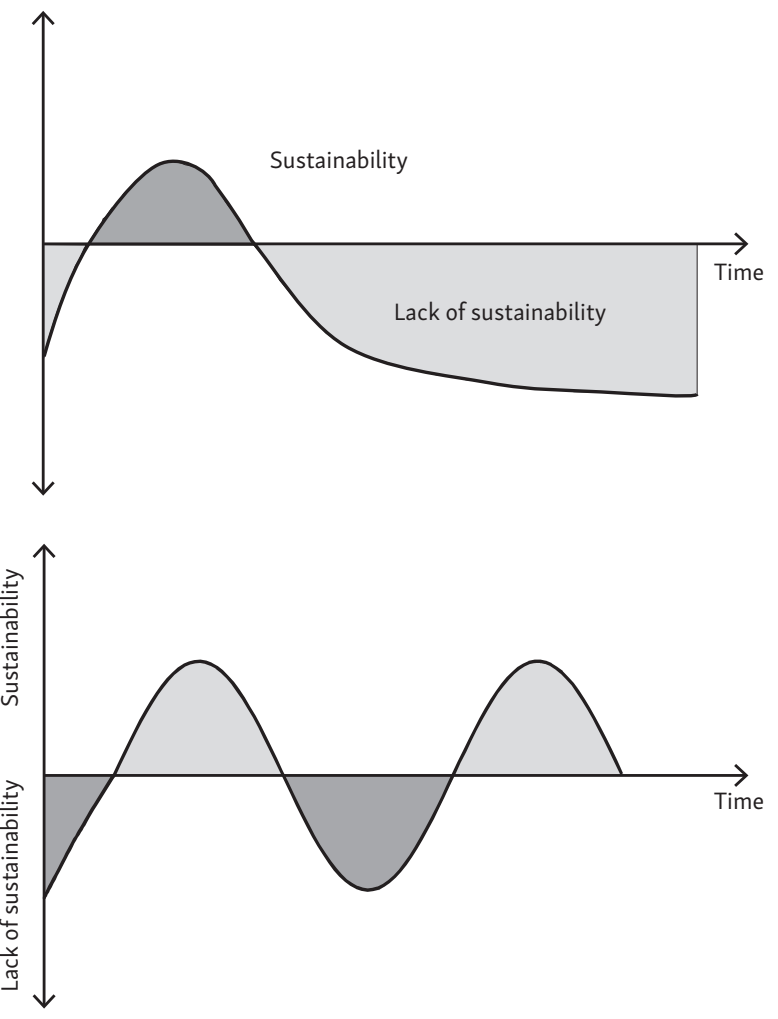

Fig. 3 - Long-term lack of sustainability of tourism space / destination. Source: Butowski, 2017 (changed).
Fig. 4 - Long-term changes sustainability/unsustainability of tourism space / destination. Source: Butowski, 2017 (changed). 


\section{Assessment of the Level of Development of Tourism Space / Destination: Proposed Method}

If we agree with the statement that tourism space and tourism destination can be treated as synonyms (at least at a given level of analysis), we can also easy notice that the development of tourism destinations (therefore also tourism space) constitutes the subject of academic interest both in terms of tourism research and management studies (Santos Estevăo, Baptista Garcia, Brito Filipe 2015; and many others). However, it should also be clearly underlined that the studies on the assessment of development of tourism destinations which have been regularly conducted for at least 40 years have mostly relied on the neo-positivist approach embedded in neoliberalist ideology (Kowalczyk-Anioł 2017).

Any assessment, including the assessment of the level development of a tourism space, should be carried out within a precisely determined framework of reference; in other words, it ought to be performed using a fixed scale (absolute or relative) which indicates an accepted research perspective. To meet this end the following assumption has been made: the measure of development of tourism space is achievement in a given destination of the state of long-term sustainability with sustainability seen as an advantage of (widely understood) benefits from tourism over (widely understood) costs of tourism development, as per the aforementioned assumptions of the model of sustainable tourism. To put it more simply, a more developed tourism space is the one which in a longer period will be better able to respond to the needs of all groups of its stakeholders without exceeding the level of maximum accepted costs. The idea refers to the notions of tourism carrying capacity (O'Reilly 1986) and limits of acceptable change (Butler 1996) as well as sustainable capacity (Bodlender, Lickorish 1991; Shaw, Williams 2002), both in environmental and socio-cultural aspects. Although the key concept of the proposed method assumes - contrary to the majority of works, which have been based on the neo-positivist approach - that the borderline between sustainability and unsustainability is subjectively determined by direct and indirect stakeholders of tourism in a given area.

Accepting the aforementioned assumption stresses the fact that the assessment of the level of development of tourism space is conducted by all the stakeholders (who can be further subdivided, if necessary for more detailed analyses). When it comes to local communities, groups such as tourism entrepreneurs and their employees (tourist businesses), public administration and NGOs' representatives (who deal with tourism) and people who are not involved in the tourism business can be distinguished. On the other hand, tourists can be classified according to their motivations, social and demographic profiles. Likert scale (adapted to meet the goals of this research project) was used as a research tool (Table 2). Respondents from different subgroups where requested to express their subjective 
Table 2 - The modified Likert scale used as a research tool for assessment of the level of development of tourism space (for its sustainability or lack thereof)

\begin{tabular}{|c|c|c|c|c|c|c|c|c|c|c|c|}
\hline \multicolumn{6}{|c|}{$\begin{array}{l}\text { Insufficient benefits from tourism } \\
\text { (unsustainability in the segment of benefits) }\end{array}$} & \multicolumn{6}{|c|}{$\begin{array}{l}\text { Sufficient benefits from tourism } \\
\text { (the state of sustainability in the segment of benefits) }\end{array}$} \\
\hline 0 & 1 & 2 & 3 & 4 & 5 & 6 & 7 & 8 & 9 & 10 & 11 \\
\hline \multicolumn{6}{|c|}{$\begin{array}{l}\text { Acceptable costs of tourism development } \\
\text { (the state of sustainability in the segment of costs) }\end{array}$} & \multicolumn{6}{|c|}{$\begin{array}{l}\text { Unacceptable costs of tourism development } \\
\text { (unsustainability in the segment of costs) }\end{array}$} \\
\hline 0 & 1 & 2 & 3 & 4 & 5 & 6 & 7 & 8 & 9 & 10 & 11 \\
\hline
\end{tabular}

Source: Butowski, 2017 (changed).

assessment of the level of the benefits gained and costs borne, taking into account the model conditions of sustainability (or unsustainability). In this way, the proposed method can be used as a practical tool for empirical verification of the model of sustainable tourism (tourism space), as presented in Figure 1.

Application of this tool allows for the quantification of the obtained qualitative information (subjective assessments). Next, the mean values for benefits and costs were calculated based on the individual answers; this made it possible to place them, in the form of a data point with determined coordinates, in the working matrix. Their relative positions in the matrix (in a particular quadrant) indicate the level of sustainability or unsustainability, as per the model assumptions. Moreover it enables assessment and comparison of the given data points by way of measuring their vector distances from theoretical points of maximum sustainability and unsustainability in particular quadrants (Fig. 5). In this way, given destinations (presented as particular data points) can be compared in terms of their levels of sustainability or unsustainability (i.e. which of them is more sustainable or less unsustainable). This should make the interpretation of the received results simpler and clearer. See Figure 5, where:

- area $A$ corresponds to the function $\mathrm{f}_{\text {(Usтв) }}$ and area OACunav in the model graph

- area $B$ corresponds to the function $f_{(\text {(ST) }}$ and area ABCstmaxCunav in the model graph

- area $\mathrm{C}$ corresponds to the function $\mathrm{f}_{\text {(USTC) }}$ and area BCFCstmax in the model graph

- area $\mathrm{D}$ corresponds to the function $\mathrm{f}_{\text {(USTвC) }}$ and area CDEF in the model graph

- data point a (with the coordinates: 5.5, 0): maximal theoretical unsustainability in the segment of benefits

- data point $b$ (with the coordinates: 0,11 ): maximal theoretical sustainability

- data point c (with the coordinates: 11, 5.5): maximal theoretical unsustainability in the segment of costs

- data point d (with the coordinates: 11, 0): maximal theoretical unsustainability in both segments (benefits and costs). 


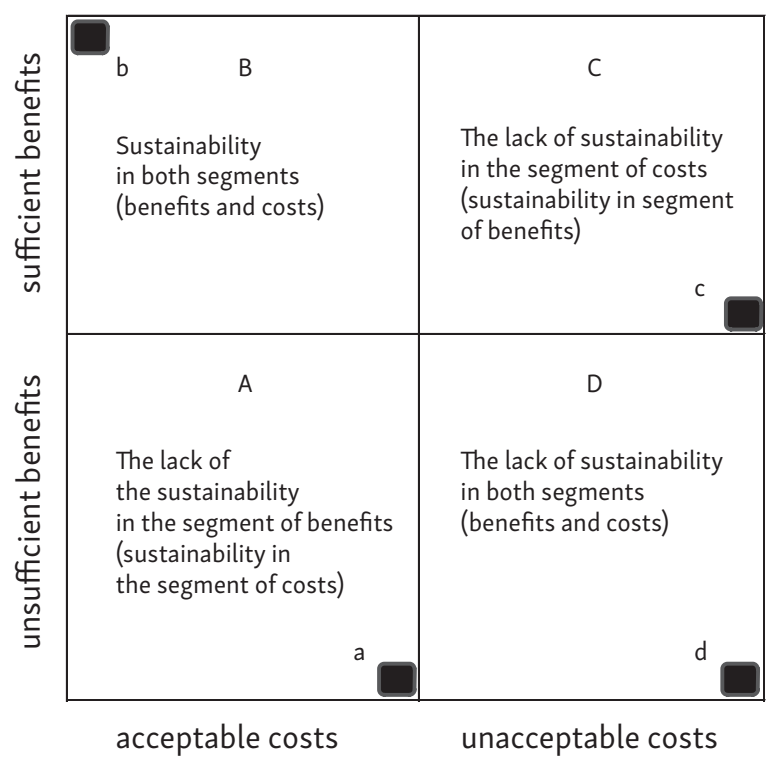

Fig. 5 - Working matrix with theoretical data points of maximum sustainability and maximum unsustainability in particular segments (benefits and/or costs). Source: Butowski, 2017 (changed).

\section{Empirical verification}

The method has been tested empirically insix popular Polish tourist resorts. Three of them (Hel, Jastarnia and Mielno) are located on the Baltic sea coast, two other (Mikołajki and Węgorzewo) - in the Mazury lakes region and the sixth (Inowłódz) - in the Central Poland forest region (Fig. 6).

All the towns are characterized by a relatively similar socio-economic potential and tourist profiles. The research was conducted in 2015 (Jastarnia), 2016 (Mikołajki, Wegorzewo, Hel, Mielno) and 2017 (Inowłódz). In each locality, around 100 respondents (about $50 \%$ of tourists and $50 \%$ of local inhabitants) were interviewed (except Jastarnia and Inowłódz; Table 3$)^{5}$. To avoid misunderstandings which could occur among informants (concerning the meaning of particular terms and the applied rules of evaluation - by means of the adopted Likert scale) all interviews were individually carried out and (where necessary) the more detailed explanations were given. Additionally, to self-test the answers presented by respondents (and to better understand opinions formulated by them), they were also asked to verbally explain their assessment. However, these interesting qualitative contents expressed by informants do not form a part of this report.

5 Respondents were interviewed by $3^{\text {rd }}$ year students of tourism from the University of Warmia and Mazury, Faculty of Environmental Studies, as well as the University of Radom (Jastarnia) and the University of Lodz (Inowłódz). 


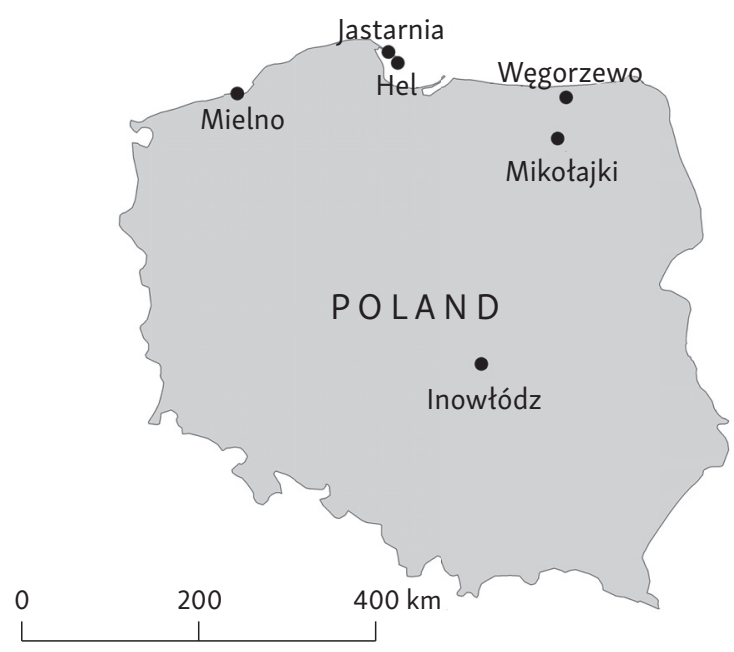

Fig. 6 - Towns where the empirical research was conducted

The obtained results indicate that (considering all the opinions of the respondents, i.e. both tourists' and local communities') tourism space was sustainable in each locality. This means that benefits overweighed costs and, at the same time, the acceptable level of costs was not exceeded and the benefits achieved at least the minimum satisfactory level. However, some differences (sometimes significant) occurred between particular towns (Fig. 7).

It is clear that the best situation occurs in the case of Hel, which is characterized by the smallest vector distance to point $b$ (maximum theoretical sustainability) and the biggest vector distances to points a, $c, d$ (which denote maximum theoretical unsustainabilities in the segments of benefits and/or costs). On the other hand, the

Table 3 - Number of respondents and basic data of the towns (2016)

\begin{tabular}{|c|c|c|c|c|c|c|c|}
\hline \multirow[t]{2}{*}{$\begin{array}{l}\text { Towns } \\
\text { (boroughs) }\end{array}$} & \multirow[t]{2}{*}{$\begin{array}{l}\text { Number of } \\
\text { inhabitants }\end{array}$} & \multirow[t]{2}{*}{$\begin{array}{l}\text { Number of } \\
\text { respondents }\end{array}$} & \multicolumn{2}{|c|}{$\begin{array}{l}\text { Number of tourist } \\
\text { accommodation } \\
\text { establishments }\end{array}$} & \multicolumn{2}{|c|}{ Number of rooms ** } & \multirow[t]{2}{*}{$\begin{array}{l}\text { Localization / main tourist } \\
\text { attraction }\end{array}$} \\
\hline & & & Total & $\begin{array}{l}\text { All-year- } \\
\text { round }\end{array}$ & Total & $\begin{array}{l}\text { All-year- } \\
\text { round }\end{array}$ & \\
\hline $\mathrm{Hel}$ & 3,444 & 100 & 27 & 8 & 758 & 305 & Baltic Sea coast \\
\hline Inowłódz & 3,828 & 185 & 10 & 10 & 1,031 & 1,031 & Central Poland forest region \\
\hline Jastarnia & 3,782 & 63 & 72 & 14 & 5,405 & 1,617 & Baltic Sea coast \\
\hline Mielno & 4,975 & 100 & 219 & 32 & 17,138 & 3,689 & Baltic Sea coast \\
\hline Mikołajki & 8,287 & 98 & 23 & 14 & 3,392 & 2,758 & Mazury Lakes region \\
\hline Węgorzewo & 17,056 & 100 & 13 & 7 & 780 & 365 & Mazury Lakes region \\
\hline
\end{tabular}

Notes: ${ }^{*}$ The data concern accommodation facilities which have 10 or more beds. ${ }^{* *}$ In establishments which have 10 or more beds. 


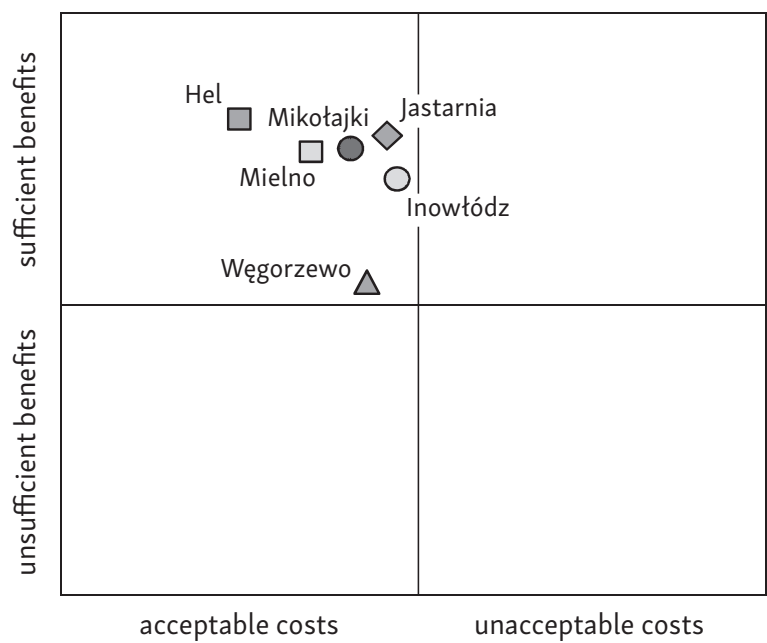

Fig. 7 - Position of towns (in relation to benefits and costs of tourism) in the working matrix (according to all respondents). Source: Butowski, 2017 (changed and completed).

town of Węgorzewo is placed close to the border line of sustainability/unsustainability in terms of benefits - with a relatively high level of costs (even if within the boundaries of sustainability). The four remaining localities are characterized by similar profiles, i.e. rather high levels of benefits and reasonable levels of costs (all within the boundaries of sustainability), although the lowest occurred in Mikołajki and the highest - in Inowłódz. To sum these results up, one can state that tourism space was the most developed in Hel, followed by, respectively, Mielno, Mikołajki, Jastarnia and Inowłódz. The lowest level of development of tourism space was noted in the case of Węgorzewo. The ranking of towns in terms of the development of tourism space has been established by means of measuring their vector

Table 4 - Level of development of tourism space in the particular towns according to all respondents*

\begin{tabular}{lcccccccc}
\hline Locality & $\begin{array}{c}\text { Average } \\
\text { value of } \\
\text { benefits }\end{array}$ & $\begin{array}{c}\text { Standard } \\
\text { deviation } \\
(\sigma)- \\
\text { benefits }\end{array}$ & $\begin{array}{c}\text { Average } \\
\text { value of } \\
\text { costs }\end{array}$ & $(\sigma)$ - costs & $\begin{array}{c}\text { Vector } \\
\text { distance } \\
\text { from } \\
\text { point a }\end{array}$ & $\begin{array}{c}\text { Vector } \\
\text { distance } \\
\text { from } \\
\text { point b }\end{array}$ & $\begin{array}{c}\text { Vector } \\
\text { distance } \\
\text { from } \\
\text { point c }\end{array}$ & $\begin{array}{c}\text { Vector } \\
\text { distance } \\
\text { from } \\
\text { point d }\end{array}$ \\
\hline Hel & 8.8 & 2.3 & 2.7 & 2.4 & 9.2 & 3.5 & 8.9 & 12.1 \\
Mielno & 8.3 & 1.5 & 3.8 & 1.6 & 8.4 & 4.7 & 7.7 & 10.1 \\
Mikotajki & 8.3 & 2.6 & 4.4 & 2.3 & 8.4 & 5.2 & 7.1 & 10.1 \\
Jastarnia & 8.6 & 1.6 & 5.0 & 1.9 & 8.6 & 5.6 & 6.7 & 10.4 \\
Inowłódz & 7.8 & 2.3 & 5.2 & 2,4 & 7.8 & 6.1 & 6.2 & 9.7 \\
Węgorzewo & 5.9 & 1.7 & 4.7 & 1.5 & 5.9 & 7.0 & 6.3 & 8.6 \\
\hline
\end{tabular}

Source: Butowki, 2017 (changed and completed).

Note: ${ }^{*}$ In tables 4-7 average values of benefits and costs as well as vector distances and standard deviation are expressed in abstract numbers. Their values are only connected with the adopted Likert scale. 
Table 5 - The level of development of tourism space in particular towns according to tourists' representatives

\begin{tabular}{lccccccccc}
\hline Locality & $\begin{array}{c}\text { Number of } \\
\text { respon- } \\
\text { dents }(\mathrm{n})\end{array}$ & $\begin{array}{c}\text { Average } \\
\text { value of } \\
\text { benefits }\end{array}$ & $\begin{array}{c}\text { Standard } \\
\text { deviation } \\
(\sigma)- \\
\text { benefits }\end{array}$ & $\begin{array}{c}\text { Average } \\
\text { value of } \\
\text { costs }\end{array}$ & $\begin{array}{c}(\sigma)- \\
\text { costs }\end{array}$ & $\begin{array}{c}\text { Vector } \\
\text { distance } \\
\text { from } \\
\text { point a }\end{array}$ & $\begin{array}{c}\text { Vector } \\
\text { distance } \\
\text { from } \\
\text { point b }\end{array}$ & $\begin{array}{c}\text { Vector } \\
\text { distance } \\
\text { from } \\
\text { point c }\end{array}$ & $\begin{array}{c}\text { Vector } \\
\text { distance } \\
\text { from } \\
\text { point d }\end{array}$ \\
\hline Hel & 50 & 8.7 & 2.2 & 2.9 & 2.2 & 9.1 & 3.7 & 8.7 & 11.9 \\
Mielno & 50 & 8.1 & 1.4 & 3.6 & 1.3 & 8.3 & 4.6 & 7.8 & 11.0 \\
Jastarnia & 51 & 8.4 & 1.5 & 5.0 & 2.0 & 8.4 & 5.7 & 6.6 & 10.3 \\
Mikotajki & 51 & 7.5 & 2.8 & 4.6 & 2.3 & 7.5 & 5.8 & 6.7 & 9.9 \\
Inowłódz & 102 & 8.1 & 2.1 & 5.4 & 2.3 & 8.1 & 6.1 & 6.2 & 9.8 \\
Węgorzewo & 50 & 6.5 & 1.4 & 5.1 & 1.5 & 6.5 & 6.8 & 6.0 & 8.7 \\
\hline
\end{tabular}

Source: Butowski, 2017 (changed and completed).

distances from point $b$ (maximal theoretical point of sustainability) - where the lower the value, the better the position in the ranking. The values of the remaining vector distances (from points $a, c$ and $d$ ) indicate the situations of towns in relation to theoretical maximum points of unsustainabilities in the particular segments of (costs and/or benefits; Fig. 5) - the higher the value, the better the situation of the given town (Table 4). And so, taking into account the segment of benefits, the best situation takes place in Hel (the vector value from point a as the theoretical maximal point of unsustainability in this segment is 9.2), followed by Jastarnia (8.6) then by Mielno (8.4) and Mikołajki (8.4), Inowłódz (7.8) and by Wegorzewo (5.9). In the same way one can analyze the positions of towns in relation to the segment of cost: Hel (the vector value from point $\mathrm{c}$ as the theoretical maximal point of unsustainability in the segment of cost is 8.9), Mielno (7.7), Mikołajki (7.1), Jastarnia (6.7), Wegorzewo (6.3), Inowłódz (6.2) as well as in in relation to both segments (benefits and costs): Hel (the vector value from point $d$ as the theoretical maximal point of unsustainability in both segments is 12.1), Jastarnia (10.4), Mielno (10.1), Mikołajki (10.1), Inowłódz (9.7) and Węgorzewo (8.6).

In addition, more detailed analyses regarding the assessment of sustainability made separately by tourists and local communities were carried out. In comparison with all the respondents tourists' representatives assessed as worse the situation in Mikołajki which was overhauled by Jastarnia (Table 5). On the other hand, according to the opinions of local communities, Mikołajki ranked just behind Hel, followed by Mielno, Jastarnia and Inowłodz (Table 6). Both groups of informants indicated that the best situation took place in Hel and the least favorable in Węgorzewo, which was the only case in which representatives of local communities claimed the state of unsustainability - in the segment of benefits (the value of benefits was assessed on the level of 5.3 with the boundary between sustainability and unsustainability set at the level 5.58). 
Table 6 - The level of development of tourism space in particular towns according to local communities' representatives

\begin{tabular}{lccccccccc}
\hline Locality & $\begin{array}{c}\text { Number of } \\
\text { respon- } \\
\text { dents }(\mathrm{n})\end{array}$ & $\begin{array}{c}\text { Average } \\
\text { value of } \\
\text { benefits }\end{array}$ & $\begin{array}{c}\text { Standard } \\
\text { deviation } \\
(\sigma)- \\
\text { benefits }\end{array}$ & $\begin{array}{c}\text { Average } \\
\text { value of } \\
\text { costs }\end{array}$ & $\begin{array}{c}(\sigma)- \\
\text { costs }\end{array}$ & $\begin{array}{c}\text { Vector } \\
\text { distance } \\
\text { from } \\
\text { point a }\end{array}$ & $\begin{array}{c}\text { Vector } \\
\text { distance } \\
\text { from } \\
\text { point b }\end{array}$ & $\begin{array}{c}\text { Vector } \\
\text { distance } \\
\text { from } \\
\text { point c }\end{array}$ & $\begin{array}{c}\text { Vector } \\
\text { distance } \\
\text { from } \\
\text { point d }\end{array}$ \\
\hline Hel & 50 & 9.0 & 2.3 & 2.6 & 2.6 & 9.4 & 3.3 & 9.1 & 12.3 \\
Mikotajki & 46 & 9.5 & 1.9 & 4.2 & 2.4 & 9.5 & 4.5 & 7.9 & 11.6 \\
Mielno & 50 & 8.4 & 1.6 & 4.0 & 1.9 & 8.5 & 4.8 & 7.5 & 10.1 \\
Jastarnia & 12 & 9.1 & 1.4 & 5.1 & 2.0 & 9.1 & 5.4 & 6.0 & 10.1 \\
Inowłódz & 83 & 7,3 & 2,5 & 4,9 & 2,4 & 7.3 & 6.1 & 6.4 & 9.5 \\
Węgorzewo & 50 & 5.3 & 1.9 & 4.3 & 1.5 & 5.4 & 7.2 & 6.7 & 8.5 \\
\hline
\end{tabular}

Source: Butowski, 2017 (changed and completed).

The obtained data allowed for yet another type of analysis. It concerned the assessment of tourism space by specific subgroups of respondents - separately within local communities and tourists. Thus, taking into account aggregated opinions of three subgroups (from all the towns) i.e.: representatives of: (1) public administration and NGOs (which were involved in the tourism sector), (2) tourist businesses, and (3) inhabitants not involved in tourism differences are evident. Representatives of public administration and NGOs in all the towns saw the situation in the most positive terms (very high level of benefits and low level of costs). Tourist business representatives believed that (in relation to the previous group) benefits of tourism development were lower and its costs significantly higher. Last but not least, the inhabitants who were not involved in tourism considered

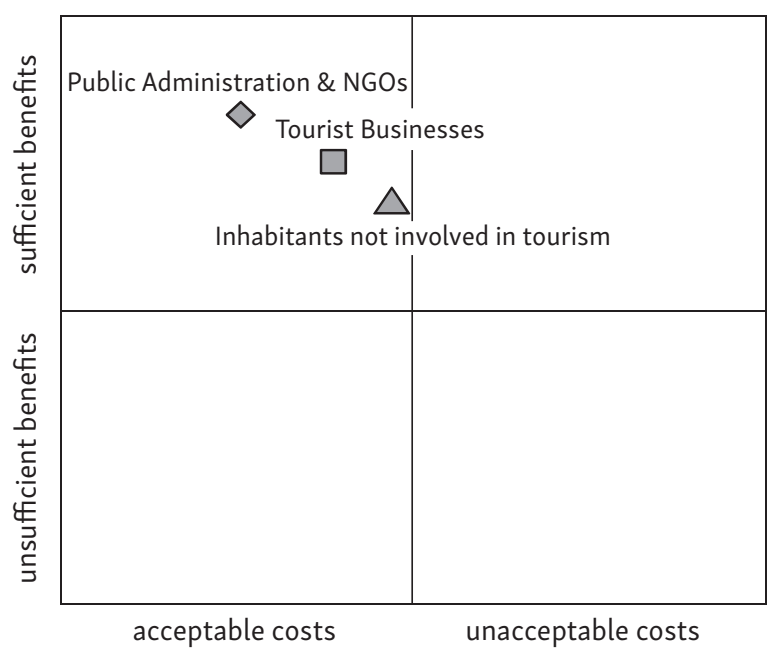

Fig. 8 - The level of development of tourism space by subgroups of local communities from all towns. Source: Butowski, 2017 (changed). 
Table 7 - The level of development of tourism space according to subgroups of tourists' representatives (in all towns)

\begin{tabular}{lcccccc}
\hline $\begin{array}{l}\text { Subgroups } \\
\text { of tourists }\end{array}$ & $\begin{array}{c}\text { Average value } \\
\text { of benefits }\end{array}$ & $\begin{array}{c}\text { Average value } \\
\text { of costs }\end{array}$ & $\begin{array}{c}\text { Vector } \\
\text { distance from } \\
\text { point a }\end{array}$ & $\begin{array}{c}\text { Vector } \\
\text { distance from } \\
\text { point b }\end{array}$ & $\begin{array}{c}\text { Vector } \\
\text { distance from } \\
\text { point c }\end{array}$ & $\begin{array}{c}\text { Vector } \\
\text { distance from } \\
\text { point d }\end{array}$ \\
\hline Active tourists & 8.2 & 4.3 & 8.3 & 5.1 & 7.2 & 10.6 \\
Passive tourists & 7.6 & 4.7 & 7.7 & 5.8 & 6.7 & 9.9 \\
Sightseeing tourists & 8.0 & 4.5 & 8.1 & 5.4 & 7.0 & 10.3 \\
Other tourists & 7.9 & 4.4 & 8.0 & 5.4 & 7.0 & 10.3 \\
\hline
\end{tabular}

Source: Butowski, 2017 (changed).

the level of development of tourism space to be the least favorable of the three groups. Nevertheless, the assessments made by all the aforementioned subgroups fell within the borders of sustainability (Fig. 8).

An analogical analysis was also carried out in relation to particular subgroups of tourists. The results are presented in Table 7.

Finally, in the context of the analyses, it should be stressed that all the results presented above are limited to a given period of time. They represent the assessment of the state of tourism (tourism space) in specific towns in relation to this time. Clearly, in order to be able to determine the level of sustainability (unsustainability) in the long run, representative research should be repeated periodically.

\section{Closing Remarks and Conclusions}

This paper concerns the concept of sustainability of tourism space. It is based on the assumption that sustainability is concerned with the level of satisfying the needs of all groups of tourism stakeholders (direct and indirect) in a given destination. In other words, it can stated that a tourism space is sustainable when benefits of tourism (in the broad sense) achieve (at least) a minimum satisfactory level (in a given destination) and, at the same time, various costs of tourism (for example, financial, economic, socio-cultural, environmental) do not exceed an acceptable level; the assessment of the benefits and costs is performed on a subjective basis by representatives of all tourism stakeholders.

On the basis of this assumption, the main thesis that sustainability of tourism space can be a synthetic measure of its development (in teleological i.e. progressive understanding) was formulated. Accordingly, a more developed tourism space is deemed to be the one which in the long run will be better able to meet the needs of people who use it (tourists visiting a given destination and the local communities) 
without exceeding a maximum level of accepted costs. Such a tourism space remains in (or is closer to) the state of sustainability. In this way, one may attempt to find an answer to the question posed at the beginning of the paper: what is the essence of sustainability of tourism space? All the aforementioned assumptions are in line with the methodology of social constructionism, which assumes involvement of all social units in the social phenomena in question (Barnes 2013; Barry, Bloor 1993) Furthermore, social constructionists treat opinions of the people concerned as the most important factor when forming their final conclusions.

The second part of the article presents certain aspects in more detail. These are concerned with the possibility of achieving the state of sustainability of tourism space and the ways of its empirical measurement which account for the complexity of this subject of investigation. In order to deal with this issue, synthetic (i.e. one which takes into consideration various contexts of tourism space) method of assessment of the tourist development of tourism space is proposed and tested in actual environments of chosen tourist towns.

Thus, the method also serves as a tool for empirical verification of the model of sustainability of tourism (tourism space), as it incorporates all theoretical model assumptions. In this way, the method can be used as a universal tool for measuring the state of sustainability (unsustainability) of different kinds of tourism space/destination.

\section{References}

BARNES, B. (2013): Scientific knowledge and sociological theory. Routledge, London, Boston.

BARNES, B., BLOOR, D. (1993): Relatywizm, racjonalizm a socjologia wiedzy: Mocny program socjologii wiedzy. IFiS PAN, Warszawa.

BLAMEY, R.K. (2001): Principles of ecotourism. In: Weaver, D.B. (ed.): The encyclopedia of ecotourism. CABI International, Wallingford, UK, 5-22.

BODLENDER, J., LICKORISH, L.J. (1991): Developing tourism destinations: policies and perspectives. Longman, Harlow, Essex.

BUTLER, R.W. (1996): The concept of carrying capacity for tourism destinations: Dead or merely buried? Progress in Tourism and Hospitality Research, 2, 3-4, 283-293.

BUTLER, R.W. (1999): Sustainable tourism: A state-of-the-art review. Tourism geographies, 1, $1,7-25$.

BUTOWSKI, L. (2012): Sustainable Tourism - A Model Approach. In: Kasimoglu, M. (ed.): Visions for Global Tourism Industry - Creating and Sustaining Competitive Strategies. InTech, Rijeka, 3-20.

BUTOWSKI, L. (2014a): Maritime Tourism Space [Morska przestrzeń turystyczna]. Turyzm, $24,1,57-64$.

BUTOWSKI, L. (2014b): Model of sustainable tourism. Theoretical and empirical approach. Folia Turistica, 33, 9-33.

BUTOWSKI, L. (2015): Morska przestrzeń turystyczna. Aspekty praktyczne i teoretyczne. In: Durydiwka, M., Duda-Gromada, K. (eds.): Przestrzeń w turystyce: Znaczenie i wykorzystanie. Wydział Geografii i Studiów Regionalnych Uniwersytetu Warszawskiego, Warszawa, 53-65. 
BUTOWSKI, L. (2017): Tourist sustainability of destination as a measure of its development. Current Issues in Tourism. DOI: 10.1080/13683500.2017.1351926.

CAZELAIS, N., NADERU, R., BEAUDET, G. (2000): L'espace touristique. Presses de l'université du Québec. Sainte-Foy (Québec).

CHOJNICKI, Z. (2005): Charakter i sytuacja nauki o turystyce - rozważania metodologiczne. Zeszyty Naukowe Wyższej Szkoły Gospodarki w Bydgoszczy, 3, 2, 11-23.

COCCOSSIS, H., PARPAIRIS, A., NIJKAMP, P. (1995): Assessing the interaction between heritage, environment and tourism: Mykonos. Sustainable tourism development, 107-125.

DURYDIWKA, M., DUDA-GROMADA, K., eds. (2015): Przestrzeń w turystyce. Znaczenie i wykorzystanie. Wydział Geografii i Studiów Regionalnych Uniwersytetu Warszawskiego, Warszawa.

DRZEWIECKI, M. (1992): Wiejska przestrzeń rekreacyjna. Instytut Turystyki, Warszawa.

FERRI, M.A. (2014): A Business Model for Accesible Tourism. In: Aiello, L. (ed.): Handbook of Research on Management of Cultural Products: E-Relationship Marketing and Accesibility Perspectives. IGI Global, 287-302.

FORSYTH, T. (1997): Environmental responsibility and business regulation: The case of sustainable tourism. The Geographical Journal, 163, 3, 270-280.

GOŁEMBSKI, G. (2002): Metody stymulowania rozwoju turystyki w ujęciu przestrzennym. Wydawnictwo Akademii Ekonomicznej w Poznaniu, Poznań.

HARRIS, R., LEIPER, N. (1995): Sustainable tourism: an Australian perspective. ButterworthHeinemann, Sydney.

HUSBANDS, W.C. (1983): Tourists space and tourist attraction, an analysis of the destination choices of European travelers. Leisure Sciences, 5, 4, 289-307.

HUNTER, C. (1997): Sustainable tourism as an adaptive paradigm. Annals of tourism research, $24,4,850-867$.

JAŁOWIECKI, B. (2010): Społeczne wytwarzanie przestrzeni. Wydawnictwo Naukowe SCHOLAR, Warszawa.

JENKINS, O. (2003): Photography and travel brochures: the circle of representation. Tourism Geographies, 5, 305-328.

JOKINEN, E., McKIE, D. (1997): The Disorientated Tourist: The Figuration of the Tourist in Contemporary Cultural Critique. In: Rojek, C., Urry, J. (eds.): Touring Cultures, Routledge, London, 23-51.

KORSTANJE, M. (2017): Introduction to Tourism Security: Tourism in the Age of Terrorism. In: Vasant, P., Kalaivanthan, M. (eds.): Handbook of Research on Holistic Optimization Techniques in the Hospitality, Tourism, and Travel Industry. IGI Global, 263-285.

KOWALCZYK, A. (2010): Turystyka zrównoważona. Wydawnictwo Naukowe PWN, Warszawa.

KOWALCZYK, A. (2014): Fenomenologia przestrzeni turystycznej. Turyzm, 24, 1, 9-16.

KOWALCZYK-ANIOE, J. (2017): Społeczno-ekonomiczne dysfunkcje rozwoju monokultury turystycznej na wschodnim wybrzeżu meksykańskiego Jukatanu. Ekonomiczne Problemy Turystyki, 1, 37, 207-220. DOI: 10.18276/ept.2017.1.37-16.

KRIPPENDORF, J. (1986): Tourism in the system of industrial society. Annals of Tourism Research, 13, 4, 517-532.

LANFANT, M.F., GRABURN, N.H. (1992): International tourism reconsidered: the principle of the alternative. In: Smith, V.L., Eadington, W.R. (eds.): Tourism alternatives: Potentials and problems in the development of tourism. Philadelphia, University of Pennsylvania Press, 88-112.

LESLIE, D. (2012): Responsible Tourism: Concepts, Theory and Practice. CABI International, Oxfordshire (UK), Cambridge (MA). 
LISZEWSKI, S. (1995): Przestrzeń turystyczna. Turyzm, 5, 2, 87-103.

LIU, Z. (2003): Sustainable tourism development: A critique. Journal of sustainable tourism, $11,6,459-475$.

MEYER, B. (2004): Turystyka jako ekonomiczny czynnik kształtowania przestrzeni. Rozprawy i Studia/Uniwersytet Szczeciński, 545. Szczecin.

MIOSSEC, J.M. (1976): Eléments pour une théorie de l'espace touristique. Les Cahiers du Tourisme. C-36. CHET, Mintel, Aix-en-Provence.

MIOSSEC, J.M. (1977): Un modèle de l'espace touristique. Espace géographique, 1, 41-48.

NIEZGODA, A. (2006): Obszar recepcji turystycznej w warunkach rozwoju zrównoważonego (A tourist destination area in terms of sustainable development). Wydawnictwo Akademii Ekonomicznej w Poznaniu, Poznań.

OPPERMANN, M. (1993): Tourism space in developing countries. Annals of Tourism Research, $20,3,535-556$.

O'REILLY, A.M. (1986): Tourism carrying capacity: Concept and issues. Tourism Management, 7, 4, 254-258.

PAWLIKOWSKA-PIECHOTKA, A., ŁUKASIK, N., OSTROWSKA-TRYZNO, A., PIECHOTKA, M., SAWICKA, K. (2017): Holistic Technical Solutions to Enhance Accessible Tourism in the UNESCO World Heritage Sites. In: Vasant, P., Kalaivanthan, M. (eds): Handbook of Research on Holistic Optimization Techniques in the Hospitality, Tourism, and Travel Industry. IGI Global, 1-26.

SANTOS ESTEVĂO, C.M., BAPTISTA GARCIA, A.R., BRITO FILIPE, S.M.I.F. (2015): What are the Most Critical Factors for Competitiveness of a Tourism Destination? In: Carmo Farinha, L.M., Ferreira, J.J.M., Lawton Smith, H., Bagchi-Sen, S. (eds): Handbook of Research on Global Competitive Advantage through Innovation and Entrepreneurship. IGI Global, 261-287.

SHAW, G., WILLIAMS, A.M. (2002): Critical Issues in Tourism: A Geographical Perspective. Wiley-Blackwell.

TUAN, Y.F. (1987): Przestrzeń i miejsce. Państwowy Instytut Wydawniczy, Warszawa.

TRIBE, J. (2006): The truth about tourism. Annals of Tourism Research, 33, 2, 360-381.

URRY, J. (2001): The Tourist Gaze: Leisure and Travel in Contemporary Society. TCS, London.

URRY, J. (2007): Spojrzenie turysty. Wyd. Naukowe PWN, Warszawa.

WARSZYŃSKA, J. (1986): Problemy badawcze geografii turyzmu. Folia Geographica, Geographia Oeconomica, 19, 59-63.

WARSZYŃSKA, J., JACKOWSKI, A. (1978): Podstawy geografii turyzmu. PWN, Warszawa.

WIECZORKIEWICZ, A. (2012): Apetyt turysty. O doświadczaniu świata w podróżach. Seria Horyzonty Nowoczesności 66, Towarzystwo Autorów i Wydawców Prac Naukowych Universitas, Kraków.

WIĘCKOWSKI, M. (2014): Przestrzeń turystyczna - próba nowego spojrzenia. Turyzm, 24, 1, 17-24.

WŁODARCZYK, B. (2009): Przestrzeń turystyczna. Istota, koncepcje, determinanty rozwoju. Wydawnictwo Uniwersytetu Łódzkiego, Łódź.

WŁODARCZYK, B. (2011): Procesy kształtujące przestrzeń turystyczną. Turyzm, 21, 1-2, 59-66. WŁODARCZYK B. (2014): Przestrzeń w turystyce, turystyka w przestrzeni - o potrzebie podziałów i klasyfikacji. Turyzm, 24, 1, 25-35. 